\title{
Peran Perguruan Tinggi sebagai Agen Perubahan Moral Bangsa (Studi Kasus Peran Konsep Diri terhadap Karakter Mulia pada Mahasiswa di Universitas X Surabaya)
}

\author{
Angkawijaya, Y.F., Program Studi Psikologi, Universitas Pembangunan Jaya \\ yulius.fransisco@upj.ac.id
}

\begin{abstract}
Although Indonesia highly holds religious and cultural values, there seems to be a moral degradation in every community currently. The number of teens criminal acts are increasing every year indicating that today's youngster doesn't have a noble character. Noble character is generally demonstrated by each individual who has a positive self-concept. The goal of this research is to find out the effect of self-concept towards student's noble character and also to see its impact in regards to be used as an educational guide. This research used quantitative approach and ex-post facto method. This research used incidental sampling technique on 100 college students from various major in Universitas $X$ located in Surabaya. The instruments used in this research were Noble Character Scale and Self-Concept Scale. The results showed that there is a significant impact from self-concept towards noble character.

Keywords : noble character, self-concept, college's role
\end{abstract}

\begin{abstract}
Abstrak : Indonesia walaupun menjunjung tinggi nilai-nilai agama dan budaya namun pada saat ini tengah mengalami kemerosotan moral pada semua kalangan. Angka kriminalitas pada usia anak sebagai pelaku kejahatan kian bertambah setiap tahunnya, mengindikasikan bahwa saat ini generasi muda tidak memiliki karakter mulia. Karakter mulia pada umumnya didemonstrasikan oleh individu yang memiliki konsep diri positif. Tujuan dari penelitian ini adalah untuk mengetahui pengaruh konsep diri terhadap karakter mulia mahasiswa serta menunjukkan besaran pengaruhnya untuk dapat digunakan sebagai pedoman pendidikan. Penelitian ini menggunakan pendekatan kuantitatif dengan metode $e x$ post facto. Teknik sampling yang digunakan adalah incidental sampling kepada 100 mahasiswa dari berbagai jurusan di Universitas X Surabaya. Instrumen penelitian yang digunakan adalah Skala Karakter Mulia dan Skala Konsep Diri. Hasil penelitian menunjukkan bahwa konsep diri memiliki pengaruh yang signifikan terhadap karakter mulia.
\end{abstract}

Kata Kunci : karakter mulia, konsep diri, peran perguruan tinggi

\section{PENDAHULUAN}

Indonesia merupakan salah satu negara di kawasan Asia yang menjunjung tinggi nilai-nilai agama dan budaya. Kehidupan masyarakat diatur oleh berbagai norma dan aturan yang berlaku untuk mencapai keteraturan di dalam kehidupan berbangsa dan bernegara. Norma dan aturan yang ada pada saat ini tidak lagi mampu menahan kemerosotan moral bangsa. Tahun 2016, Indonesia hanya berada di posisi ke-90 dari 176 negara dengan skor 37 dari skala 0-100 berdasarkan Indeks Persepsi Korupsi yang dirilis oleh Transparency International (2017). Indonesia jauh tertinggal dalam penanganan korupsi jika dibandingkan Denmark, Selandia Baru, dan Finlandia yang menduduki tiga besar dalam Indeks Persepsi Korupsi.

Kemerosotan moral tidak hanya terjadi di kalangan pejabat yang melaku- 
kan korupsi, tetapi juga terjadi di kalangan masyarakat yang diindikasikan dengan angka kriminalitas. Berdasarkan Catatan Tahunan 2016 yang dirilis Komnas Perempuan menyatakan pada tahun 2015 terjadi kenaikan pemerkosaan sebesar $72 \%$ dari tahun sebelumnya, yaitu sebanyak 2.399 kasus.

Di sisi lain, kasus kejahatan dengan pelaku masih berusia anak juga meningkat. Data yang dirilis KPAI (dalam Maskur, 2016) mencatat pada tahun 2015, terjadi kenaikan $17.9 \%$ anak sebagai pelaku kejahatan dibandingkan tahun sebelumnya. Data tersebut menunjukkan terjadi 67 kasus pada tahun 2014 dan meningkat menjadi 79 kasus. Sementara pada tahun 2015, kasus anak sebagai pelaku tawuran meningkat $123.9 \%$ dari 46 kasus pada tahun 2014 menjadi 103 kasus.

Mantan Ketua Mahkamah Konstitusi Republik Indonesia, Prof. Dr. Moh. Mahfud MD (dalam Makur, 2012) mengatakan bahwa kemerosotan moral bangsa tidak lepas dari tanggung jawab lembaga pendidikan. Lebih lanjut dikatakan bahwa pendidikan yang diterapkan di lembaga-lembaga pendidikan hanya mendidik anak supaya memiliki kecerdasan otak dan tidak pernah mendidik untuk membangun karakter. Pernyataan Prof. Dr. Moh. Mahfud MD secara jelas menunjukkan peran strategis dari pendidikan terhadap pembangunan moral bangsa. Sejalan dengan hal tersebut, Ali (2009) mengatakan bahwa karakteristik dari pendidikan nasional meliputi tiga unsur, yaitu kecerdasan yang mencakup kecerdasan intelektual, emosional dan spiritual; akhlak mulia; dan karakteristik pribadi. Karakteristikkarakteristik dari pendidikan nasional menunjukkan salah satu fungsi dari pendidikan adalah sebagai pembentuk dari moral dan khususnya karakter dari setiap peserta didik.

Perguruan tinggi merupakan salah satu institusi pendidikan yang bertanggung jawab mempersiapkan peserta didiknya untuk menjadi anggota yang baik dalam masyarakat. Tanggung jawab perguruan tinggi tersebut tercakup dalam Tri Dharma Perguruan Tinggi, yaitu pendidikan dan pengajaran; penelitian; dan pengabdian kepada masyarakat. Ali (2009) mengatakan bahwa dalam kaitannya dengan Tri Dharma Perguruan Tinggi, perguruan tinggi mempunyai tiga fungsi utama, yaitu pengembangan sumber daya manusia, pengembangan sains dan teknologi, dan sebagai agen perubahan sosial. Salah satu kandungan terbesar dari pengabdian kepada masyarakat adalah menjadi agen perubahan sosial, yaitu mengupayakan perubahan sosial ke arah yang lebih baik (Ali, 2009). Peran sebagai agen sosial dalam konteks kemerosotan moral dapat dipandang sebagai agen yang melakukan penyadaran moral guna terbangunnya kembali moral bangsa dan karakter tiap individu.

Kamus psikologi yang diterbitkan oleh American Psychological Association (APA) di mana VandenBos (2007) sebagai editor mendefinisikan kata karakter sebagai "the totality of an individual's attributes and personality traits, particulary his or her characteristic moral, social, and religious attitudes". Berdasarkan definisi tersebut maka diketahui bahwa karakter mempunyai peran penting dalam pembentukan perilaku seseorang.

Karakter erat kaitannya dengan nilai-nilai budaya yang dianut oleh suatu bangsa. Hedipuspita (2012) menuliskan bahwa Indonesia merupakan negara agamis, yang mengutamakan nilai keagamaan, di sisi lain, negeri ini juga adalah negara beragam agama. Keterkaitan antara karakter dengan nilai agama merupakan hal yang sulit terpisahkan. Marzuki (2013) kemudian mendefinisikan karakter mulia sebaga karakter yang dihasilkan dari proses penerapan ajaran agama. Karakter mulia sebagai produk dari ajaran agama tentu mempunyai perspektif yang berbeda dari setiap agama.

Karakter dipengaruhi oleh berbagai faktor. Mu'in (2011) mengatakan bahwa 
terdapat lima aspek diri berkaitan dengan pembentukan karakter individu, yaitu sikap, emosi, kepercayaan, kebiasaan, dan konsep diri. Konsep diri seseorang akan mempengaruhi karakter dari orang tersebut. Mu'in (2011) menjelaskan lebih lanjut bahwa konseps diri sangat penting untuk diperhatikan bagi siapa saja yang peduli pada pembangunan karakter. Ahli lainnya, yaitu B.W. Farmer, Farmer, dan Burrow (2008) juga mengatakan bahwa, " $a$ person with a strong self-concept is usually one who demonstrates good character".

Konsep diri memiliki peran di dalam berbagai perilaku yang dilakukan oleh individu (Haryanto, 2010). Peran konsep diri dalam kehidupan individu sangat penting namun seringkali individu mendapat berbagai hal negatif yang membuat konsep dirinya menjadi rendah. Berbagai penelitian empiris (Alfiah, 2011; Maria, 2007; Rinawati, 2009; Windarti, 2013) membuktikan bahwa terdapat hubungan negatif yang signifikan antara konsep diri dan kenakalan remaja. Oleh karena itu, konsep diri memiliki peran strategis dalam memperbaiki moral bangsa khususnya pada konteks dunia pendidikan di Indonesia saat ini.

\section{Pertanyaan Penelitian}

Pertanyaan penelitian ini adalah: apakah konsep diri berperan dalam pembentukan karakter mulia?

\section{Tujuan Penelitian}

Penelitian ini bertujuan bertujuan untuk mengetahui apakah konsep diri berperan dalam pembentukan karakter mulia. Selain itu, penelitian ini bertujuan untuk mengetahui seberapa besar varians karakter mulia yang dapat dijelaskan oleh varians konsep diri.

\section{KAJIAN PUSTAKA}

Novak (dalam Lickona, 2013) mengatakan bahwa karakter merupakan campuran kompatibel dari seluruh kebaikan yang diidentifikasikan oleh tradisi religius, cerita sastra, kaum bijaksana, dan kumpulan orang berakal sehat yang ada dalam sejarah. Definisi tersebut kemudian diperinci oleh ahli lainnya berupa kumpulan nilai (values). Philips (dalam Mu'in, 2011) mengatakan bahwa karakter adalah kumpulan tata nilai menuju pada suatu sistem yang melandasi pemikiran, sikap, dan perilaku yang ditampilkan. Senada dengan hal tersebut, Jalal (dalam Zubaedi, 2012) mendeskripsikan karakter sebagai nilainilai yang khas yang baik yang terpatri dalam diri dan terejawantahkan dalam perilaku.

Bailey (2012) memaparkan aspekaspek dari karakter, antara lain: patriotisme, kemurahan, penguasaan diri, kesabaran, kesetiaan, rasa bersyukur. Sementara itu Peterson dan Seligman (2004) menjabarkan 24 aspek character strength, antara lain: kreativitas, keingintahuan, keterbukaan pikiran, kecintaan pada pembelajaran, perspektif, keberanian, kegigihan, integritas, vitalitas, kasih, kebaikan, kecerdasan sosial, kewarganegaraan, keadilan, kepemimpinan, memaafkan dan belas kasihan, rendah hati, kebijaksanaan, regulasi diri, apresiasi keindahan, bersyukur, harapan, humor, dan spiritualitas.

Komponen karakter yang disampaikan oleh Bailey (2012) serta Peterson dan Seligman (2004) digunakan sebagai framework dari komponen karakter mulia dalam penelitian ini. Selanjutnya peneliti menggunakan komponen karakter mulia yang disesuaikan dengan nilai dan budaya yang digunakan oleh Universitas X Surabaya. Berdasarkan telaahan nilai dan budaya Universitas X Surabaya, maka komponen akhir dari karakter mulia dalam penelitian ini adalah kasih, kesabaran, kemurahan, kesetiaan, pengendalian diri, rasa bersyukur, dan memaafkan

Konsep diri dipahami sebagai persepsi dan perasaan dari individu mengenai dirinya sendiri terlepas dari realistis atau tidak (Fitts, dalam Sack \& 
Silberman, 2003). Selanjutnya Fitts (dalam Di lorio, 2005) mengemukakan bahwa konsep diri memiliki lima aspek, antara lain:

1. diri fisik (physical self) merujuk pada deskripsi diri dari keadaan fisik individu termasuk kemampuan fisik dan penampilan fisik,

2. diri moral (moral self) merepresentasikan diri dari pandangan moral dan etika,

3. diri pribadi (personal self) menandakan perasaan berharga dan rasa lengkap sebagai seorang pribadi,

4. diri keluarga (family self) merefleksikan perasaan bernilai dan berharga sebagai bagian dari anggota keluarga, dan

5. diri sosial (social self) mengindikasikan perasaan berharga di dalam interaksi sosial dengan orang lain.

Berdasarkan kajian di atas, maka hipotesis alternatif yang diajukan dalam penelitian ini adalah terdapat pengaruh konsep diri terhadap karakter mulia mahasiswa di Universitas X Surabaya.

\section{METODOLOGI PENELITIAN}

Penelitian ini menggunakan pendekatan kuantitatif dengan metode $e x$ post facto. Total mahasiswa aktif pada Universitas $\mathrm{X}$ berjumlah sekitar 525 mahasiswa. Sampel dalam penelitian ini menggunakan 100 mahasiswa Universitas $\mathrm{X}$ Surabaya yang berasal dari berbagai jurusan. Teknik sampling yang digunakan adalah incidental sampling.

Jenis instrumen yang digunakan di dalam penelitian ini berupa skala Likert. Seluruh skala di dalam penelitian ini menggunakan format enam respon pilihan jawaban, yaitu sangat tidak setuju (STS), tidak setuju (TS), agak tidak setuju (ATS), agak setuju (AS), setuju (S), dan sangat setuju (SS). Pemberian skor untuk item favorable akan bergerak dari satu sampai enam, sedangkan untuk item unfavorable sebaliknya. Item yang akan digunakan dalam pengambilan data adalah item yang memiliki nilai corrected item-total correlation lebih besar dari .25 (Azwar, 2012).

Peneliti membuat instrument penelitian berupa penyusunan Skala Karakter Mulia dan Skala Konsep Diri. Skala Karakter Mulia dan Skala Konsep Diri disusun oleh peneliti dengan mengacu kepada faktor-faktor teoritis karakter mulia dan konsep diri. Skala Karakter Mulia yang disusun peneliti berjumlah 72 item, namun peneliti hanya memilih 30 item terbaik yang representatif terhadap seluruh dimensi dari karakter mulia. Skala Konsep Diri yang disusun peneliti berjumlah 52 item, namun peneliti hanya memilih 20 item terbaik yang representatif terhadap seluruh dimensi dari konsep diri. Peneliti menggunakan hanya total sebanyak 50 item terbaik karena semakin banyak jumlah item yang digunakan maka semakin mengurangi motivasi responden dalam mengerjakan instrument penelitian. Pemilihan 50 item terbaik berdasarkan uji coba instrument penelitian yang dilakukan sebelum pengambilan data lapangan.

Peneliti melakukan uji coba seluruh skala penelitian dengan subjek uji coba sebanyak 17 mahasiswa. Adapun 30 item terbaik dari Skala Karakter Mulia memiliki nilai corrected item-total correlation sebesar .349 sampai .949. Sementara itu, dua puluh item terbaik Skala Konsep Diri memiliki nilai corrected item-total correlation sebesar sampai .251 sampai .682 .

Validitas yang ditegakkan pada seluruh instrumen penelitian adalah validitas isi (content validity). Peneliti meminta penilaian kepada Karin L. Tanojo, S.Psi., M.Psi., Psi. sebagai expert judgment dalam bidang psikologi pendidikan. Peneliti juga meminta penilaian kepada Firmanto A. Nurcahyo, S.Psi., M.Si. sebagai expert judgment dalam bidang psikometri. Perhitungan reliabilitas dilakukan setelah peneliti menyeleksi item terbaik dari setiap skala. Reliabilitas yang digunakan dalam penelitian ini adalah internal konsistensi, yaitu formula Cronbach Alpha. Koefisien 
reliabilitas Skala Karakter Mulia adalah .950, sementara koefisien reliabilitas Skala Konsep Diri adalah .846.

\section{HASIL PENELITIAN DAN ANALISIS}

Analisis dilakukan dengan metode regresi linier. Peneliti menguji hipotesis dengan terlebih dahulu menguji kelayakan model yang digunakan. Uji $F$ menunjukkan nilai signifikansi .000 ( $p<$ .05) sehingga model tersebut dapat digunakan. Peneliti selanjutnya melakukan uji $t$ dan mendapatkan nilai signifikansi sebesar .000 $(p<.05)$ sehingga $\mathrm{H}_{0}$ tidak diterima. Koefisien determinasi $R^{2}$ dari sumbangan konsep diri terhadap karakter mulia adalah .318. Oleh karena itu dapat disimpulkan bahwa konsep diri memiliki peran yang signifikan terhadap karakter mulia sebesar $31.8 \%$.

\section{DISKUSI}

Hasil analisis yang dilakukan menunjukkan bahwa $31.8 \%$ karakter mulia dapat dijelaskan oleh variabel konsep diri, sedangkan $68.2 \%$ dijelaskan oleh variabel lain. Variabel lain yang ikut berperan dalam mempengaruhi karakter adalah spiritualitas. Naagarazan (2007) mengatakan bahwa spiritualitas mempunyai fungsi sebagai pendukung pertumbuhan karakter seseorang. Pernyataan tersebut juga diperkuat oleh John Templeton Foundation (1999) yang menulis bahwa spiritualitas dan agama berperan dalam membentuk karakter.

Values (nilai-nilai) yang dimiliki seseorang ikut membentuk karakter orang tersebut. Salah satu jenis values adalah living values (nilai-nilai kehidupan) yang bersifat universal (Oetomo, 2012). Penelitian yang dilakukan Komalasari (2012) menunjukkan bahwa living values activity-based contextual learning mempunyai pengaruh positif yang signifikan terhadap perkembangan karakter sebesar 26.2\%. Perbandingan hasil empiris dari penelitian ini dan penelitian Komalasari (2012) menunjukkan bahwa konsep diri memiliki pengaruh yang lebih besar daripada values dalam membentuk karakter seseorang.

Konsep diri telah terbukti secara empiris memiliki peran dalam membentuk karakter mulia mahasiswa. Perguruan Tinggi memiliki tanggung jawab dan peran untuk dapat meningkatkan konsep diri mahasiswa. Peran tersebut adalah dengan menyediakan atmosfer lingkungan yang positif sehingga konsep diri mahasiswa yang positif dapat diwujudkan dengan baik. Peran perguruan tinggi dalam menciptakan lingkungan yang mendukung pembentukan konsep diri dapat dilakukan dengan pembiasaan untuk menghargai orang lain. Perilaku menghargai orang lain dapat diwujudkan dengan cara: pembiasaan terhadap penggunaan katakata positif, melatih kebiasaan bertepuk tangan, dan penanaman identitas bahwa individu tersebut penting.

Penerapan praktis yang juga dapat dipraktekkan di dalam kelas saat dosen tengah mengajar mahasiswa. Dosen hendaknya mengatakan bahwa mahasiswanya pasti bisa jika berusaha daripada mengatakan mahasiswanya bodoh. Dosen juga dapat menerapkan budaya bertepuk tangan jika ada mahasiswa selesai melakukan melakukan presentasi. Selain itu, dosen dapat mengatakan bahwa mahasiswanya merupakan individu yang berharga di mata Tuhan. Langkah-langkah praktis tersebut diharapkan mampu meningkatkan konsep diri yang berdampak pada meningkatnya karakter mulia mahasiswa.

\section{SIMPULAN}

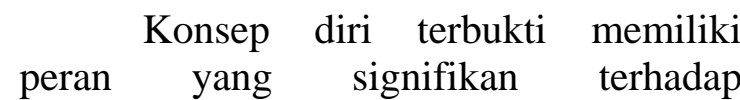
pembentukan karakter mulia di Universitas X Surabaya. Varians konsep diri mampu menjelaskan varians karakter mulia sebesar $31.8 \%$. Upaya peningkatan konsep diri dari mahasiswa dapat dilakukan dengan menghargai orang lain melalui: penggunaan kata-kata positif, bertepuk tangan setelah menyelesaikan suatu permasalahan, penanaman identitas diri 
yang positif, dan mengatakan bahwa mahasiswa pasti bisa jika berusaha. Peningkatan konsep diri diharapkan mampu meningkatkan karakter mulia mahasiswa.

\section{DAFTAR PUSTAKA}

1. Ali, M., Pendidikan untuk pembangunan nasional: Menuju bangsa Indonesia yang mandiri dan berdaya saing tinggi. Jakarta: Penerbit Imtima, 2009.

2. Alfiah, F., Hubungan antara konsep diri dengan kenakalan remaja: Penelitian di SMAN 1 Suboh Kecamatan Situbondo, Skripsi tidak dipublikasikan, Universitas Islam Negeri Maulana Malik Ibrahim, Malang, 2011.

3. Azwar, S., Penyusunan skala psikologi (Edisi Kedua). Yogyakarta: Pustaka Pelajar, 2012.

4. Bailey, J. A., Good character. Crewe: Trafford Publishing, 2004.

5. Di lorio, C. K., Measurement in health behavior: Methods for research and evaluation, San Francisco, CA: John Wiley \& Sons, Inc, 2005.

6. Farmer, B. W., Farmer, E. I., \& Burrow, J. L., Leading with character. Ohio: Thomson South-Western, 2008.

7. Haryanto, Peran konsep diri dalam menentukan perilaku. Belajar Psikologi. Diunduh dari http://belajarpsikologi.com, 2010.

8. Hedipuspita, S., Kualitas hidup mahasiswa: Spiritualitas dan konformitas sebagai prediktor wellbeing, Laporan penelitian tidak dipublikasikan, Universitas Pelita Harapan, Surabaya, 2012.

9. John Templeton Foundation, Colleges that encourage character development: A resource for parents, students, and educators. Pennsylvania: Templeton Foundation Press, 1999.

10. Komalasari, K., The living valuesbased contextual learning to develop the student's character, Journal of Social Sciences, 8(2), 2012, pp 246251.

11. Komnas Perempuan, Kekerasan terhadap perempuan meluas: Mendesak negara hadir hentikan kekerasan terhadap perempuan di ranah domestik, komunitas dan negara, Komisi Nasional Anti Kekerasan terhadap Perempuan, Diakses dari http://komnasperempuan.go.id/siaranpers-komnas-perempuan-catatantahunan-catahu-2016-7-maret-2016, 2016.

12. Lickona, T., Mendidik untuk membentuk karakter: Bagaimana sekolah dapat mengajarkan sikap hormat dan tanggung jawab. Jakarta: Bumi Aksara, 2013.

13. Makur, M., Mahfud MD: Indonesia alami kemerosotan moral, Kompas. Diunduh dari http://nasional.kompas.com/ $\mathrm{read} / 2012 / 08 / 23 / 1124255 /$ Mahfud.M D.Indonesia.Alami.Kemerosotan.Mor al, 2012.

14. Maria, U., Peran persepsi keharmonisan keluarga dan konsep diri terhadap kecenderungan kenakalan remaja, Tesis program master, Universitas Gadjah Mada (UGM), Yogyakarta, 2007.

15. Marzuki, Revitalisasi pendidikan agama di sekolah dalam pembangunan karakter bangsa di masa depan. Jurnal Pendidikan Karakter, 3(1), 2013, pp 64-76.

16. Maskur, F., Catatan akhir tahun KPAI: Anak sebagai pelaku kejahatan meningkat, Bisnis.com. Diunduh dari http://lifestyle.bisnis.com/read/201601 02/236/506440/catatan-akhir-tahunkpai-anak-sebagai-pelaku-kejahatanmeningkat

17. Mu'in, F., Pendidikan karakter: Konstruksi teoritik dan praktik. Yogyakarta: Ar-Ruzz Media, 2011.

18. Naagarazan, R. S., A textbook on professional ethics and human values. 
New Delhi: New Age International Ltd., Publishers, 2007.

19. Oetomo, H., Pedoman dasar pendidikan budi pekerti. Jakarta: Prestasi Pustaka Publisher, 2012.

20. Peterson, C., \& Seligman, M. E. P., Character strengths and virtues: A handbook and classification. New York, NY: Oxford University Press, Inc., 2004.

21. Rinawati, D., Hubungan konsep diri dan perilaku asertif dengan kenakalan remaja di SMAN 9 Malang, Skripsi tidak dipublikasikan, Universitas Negeri Malang, Malang, 2009.

22. Roedy, Angka kriminalitas anak meloncak, Lintas Magetan, Diakses dari http://www.lintasmagetan.com, 2012.

23. Sack, S. Z., \& Silberman, R. K., Social skills. Dalam A. J. Koenig \& M. C. Holbrook (Eds.), Foundation of education: Volume II, instructional strategies for teaching children and youths with visual impairments (hal. 616-652). New York: AFB Press, 2003.

24. Transparency International, Corruption perceptions index 2016. Transparency International. Diunduh dari

http://www.transparency.org/news/fea ture/corruption_perceptions_index_20 $16,2017$.

25. VandenBos, G. R. (Ed.)., APA dictionary of psychology, Washington, DC: American Psychology Association, 2007.

26. Windarti, Y., Hubungan konsep diri dengan kejadian kenakalan remaja pada siswa kelas VIII di SMP Bina Bangsa Surabaya, Tesis program master tidak dipublikasikan, STIKES Yarsis, Surabaya, 2013.

27. Zubaedi, Desain Pendidikan Karakter: Konsep dan Aplikasi Dalam Lembaga Pendidikan, Jakarta: Kencana., 2012. 